\title{
ANALISIS RATA-RATA GENERASI JAGUNG UNPAD TOLERAN NAUNGAN PADA SISTEM AGROFORESTRI DENGAN ALBIZIA DI JAWA BARAT
}

\section{GENERATION MEAN ANALYSIS (GMA) OF UNPAD MAIZE GENOTYPE SHADE TOLERANT UNDER AGROFORESTRY SYSTEM WITH ALBIZIA IN WEST JAVA}

\author{
Muhammad Syafii ${ }^{1)}$ dan Dedi Ruswandi ${ }^{2)}$ \\ 1) Program Studi Agroteknologi, Fakultas Pertanian Universitas Singaperbangsa Karawang \\ Jl. H. S. Ronggowaluyo Teluk Jambe Karawang 41361 \\ 2) Program Studi Agroteknologi, Fakultas Pertanian Universitas Padjadjaran Bandung \\ Jl. Raya Bandung Sumedang KM.21, Sumedang 45363 \\ Korespondesi: muhammad.syafii@staff.unsika.ac.id
}

Diterima 24 September 2018 /Disetujui 5 Juli 2019

\begin{abstract}
ABSTRAK
Aksi gen yang berperan terhadap suatu karakter dapat dipelajari dan dijadikan dasar dalam menentukan metode seleksi kegiatan pemuliaan. Analisa rata-rata generasi (generation mean analysis) merupakan salah satu cara yang dapat digunakan untuk menduga aksi gen, baik aditif, dominan dan interaksi non-alelik (epistasis) terhadap ekspresi suatu karakter. Metode ini digunakan untuk menduga model genetik yang berperan dalam ekspresi suatu karakter. Tujuan riset untuk menduga peran gen jagung toleran naungan pada sistem agroforestri dengan albizia. Penelitian dilaksanakan pada Oktober 2015 - Maret 2016 di Kebun Percobaan Kutamandiri, Kabupaten Sumedang. Materi genetik yang digunakan adalah galur toleran naungan M7DR 4.8.8, galur peka naungan G-203-1, $F_{1}$ hasil persilangan $G-2031$ x M7DR 4.8.8, $\mathrm{F}_{2}$ keturunan dari $\mathrm{F}_{1}$, dan $\mathrm{BC}_{1} \mathrm{~F}_{1}$ dan $\mathrm{BC}_{2} \mathrm{~F}_{1}$. Hasil penelitian menunjukkan bahwa karakter jumlah baris per tongkol terdapat kesesuaian model dengan aditif-dominan dan tidak terdapat efek epistasis pada hasil persilangan antara G-2031 x M7DR 4.8.8. Model genetik $m$ [d] [h] [i] sesuai dengan karakter tinggi tanaman dan bobot pipil per tongkol; model $m$ [d] [h] [i] [l] sesuai dengan karakter panjang ruas, diameter tongkol, dan karakter bobot tongkol per tongkol; dan model $\mathrm{m}$ [d] [h] [j] [l] sesuai dengan karakter panjang tongkol. Karakter kadar klorofil tidak memiliki kesesuaian dengan model genetik yang diduga.
\end{abstract}

Kata kunci: Aditif-dominan, GMA, Jagung, Naungan.

\section{ABSTRACT}

Gene action that has a role in a character can be studied and used as a basic on determining the method of selection in breeding programs. Generation mean analysis is one of the methods that can be used to estimate the gene action, both additive, dominant and non-allelic (epistatic) interactions to the expression of a character. The method was used to predict the genetic model that plays a role in the expression of a character. The objective of the research was to predict the role of shade tolerant maize genes in the agroforestry system with albizia. The research was conducted on October 2015 - March 2016 at Kutamandiri Experiment Garden, Kabupaten Sumedang. The genetic materials was the shade tolerant line M7DR 4.8.8, shade susceptible G-203-1, $F_{1}$ derived from G-2031 x M7DR 4.8.8, $F_{2}$ breeds from $F_{1}$, and $B C_{1} F_{1}$ ISSN : 2407-7933

Cite this as: Syafii, M dan Ruswandi, D. (2019). Analisis rata-rata generasi jagung Unpad toleran naungan pada sistem agroforestri dengan albizia di Jawa Barat. Jurnal Agro, 6(1), 66-76 https://doi.org/10.15575/3301 
and $\mathrm{BC}_{2} \mathrm{~F}_{1}$. The results showed that number of row per cob character was suitable to the dominant additive model and there was no effect of epistasis on the crosses between $\mathrm{G}-2031 \mathrm{x}$ M7DR 4.8.8. The genetic model $m$ [d] [h] [i] corresponded to the plant height and the weight of seed per cob; model $m$ [d] [h] [i] [l] corresponded to the character of the length of the node, cob diameter, and cob weight per ear; and the $m[d][h][j] ~[l]$ model corresponded to the cob lenght character. The chlorophyll content character has no corresponding alleged genetic model.

Key words: Corn, GMA, Shade, Additive-dominant

\section{PENDAHULUAN}

Jagung (Zea mays L.) adalah salah satu tanaman serealia penting di dunia, setelah padi dan gandum. Jagung merupakan komoditas strategis dan bernilai ekonomis tinggi, disamping sebagai sumber karbohidrat juga sebagai salah satu komponen utama dalam industri pangan dan pakan ternak, industri biofuel, kosmetik dan sebagai bahan baku obat (farmakologi) baik di Asia, Eropa, Amerika Tengah, Amerika Selatan maupun Amerika Serikat (Ruswandi et al., 2017; Syafii et al., 2015).

Upaya peningkatan produksi jagung nasional terus dilakukan, diantaranya melalui strategi perakitan kultivar jagung unggul baru yang adaptif lingkungan serta pemanfaatan areal lahan sub optimal dan lahan agroforestri secara optimal (Syafii et al., 2015). Agroforestri merupakan sistem pengelolaan sumber daya alam yang dinamis dan berbasis ekologi, dengan memadukan berbagai jenis pohon dan tanaman sela pada bentang lahan tertentu (Gao et al., 2013; Senoaji, 2012). Potensi pengembangan jagung pada lahan agroforestri sangat prospektif terutama pada lahan penanaman albizia (Syafii et al., 2016). Penanaman jagung dibawah tegakan albizia dapat dilakukan pada tanaman belum menghasilkan, yaitu pada tahun pertama sampai tahun ketiga. Pada tahun pertama penanaman dilakukan tanpa naungan, namun pada tahun ketiga tinggi tanaman albizia dapat mencapai $6 \mathrm{~m}$ yang dapat menaungi tanaman jagung. Tanaman yang ternaungi dapat menyebabkan berkurangnya potensi genetik karena kekurangan pencahayaan sehingga mengurangsi aktivitas fotosintesis (Wang et al., 2013). Sistem agroforestri berpotensi memberikan manfaat sosial, ekonomi dan lingkungan bagi para pengguna lahan (Hairiah et al., 2002). Potensi areal lahan agroforestri di Indonesia sangat luas sekitar 14,1 juta ha dan sekitar 4,7 juta ha dapat ditanami dengan tanaman pangan (Krisnawati et al., 2011).

Program pemuliaan untuk merakit varietas jagung unggul baru pada karakter tertentu telah dilaksanakan dengan menggunakan metode yang lebih modern yaitu dengan memanfaatkan marka morfologi maupun marka molekuler (Kumar et al., 2009). Pada karakter toleransi terhadap cekaman lingkungan abiotik telah banyak ditemukan gen-gen pengendali karakter tersebut baik secara konvensional maupun menggunakan teknologi maju seperti biomolekular dan penanda molekuler (Liu \& Tollenaar, 2009). Perilaku aksi gen yang bertanggung jawab terhadap suatu karakter penting untuk 
dipelajari dan diketahui karena dapat dijadikan dasar dalam menentukan metode seleksi dan penentuan target atau tujuan suatu kegiatan pemuliaan (Trikoesoemaningtyas et al., 2017).

Analisa rata-rata generasi (generation mean analysis) merupakan salah satu cara yang dapat digunakan untuk menduga aksi gen, meliputi adanya peran gen aditif, dominan dan interaksi non-alelik (epistasis) terhadap ekspresi suatu karakter. Disamping itu, metode GMA (generation mean analysis) dapat juga digunakan untuk menduga model genetik yang berperan dalam ekspresi suatu karakter. Semakin besar jumlah generasi yang digunakan (3-6 generasi), maka semakin baik model genetik yang dapat diduga (Rao et al., 2017). Terdapat dua macam metode pendugaan, yaitu uji skala secara individu (scaling test), menduga aksi gen dan model genetik dengan menguji sejumlah generasi secara terpisah; dan uji skala gabungan (joint scaling test), menduga aksi gen dan model genetik dengan menguji sejumlah generasi secara bersama-sama dan memungkinkan dilakukannya uji kesesuaian model genetik.

Para peneliti telah menggunakan metode analisis rata-rata generasi untuk menduga aksi gen dan parameter genetik, diantaranya: Rao et al. (2017) pada tanaman padi; Ruswandi et al. (2017) pada ketahanan penyakit downy mildew pada jagung; Syukur et al. (2009) pada ketahanan penyakit antraknosa pada cabai; Dea et al. (2015) pada kapas; Deshmukh \& Gawande (2016); Farshadfar et al. (2011); Said, (2014) pada Wheat. Penelitian ini bertujuan untuk mengetahui pola pewarisan, model kendali genetik dan perilaku aksi gen pada jagung Unpad toleran naungan pada sistem agroforestri dengan albizia di Jawa Barat.

\section{BAHAN DAN METODE}

Penelitian dilaksanakan pada Oktober 2015 sampai Maret 2016 di Kebun Percobaan Desa Kutamandiri, Tanjungsari, Kab. Sumedang dibawah tegakan pohon albizia berumur 3-4 tahun dengan radiasi surya yang diterima oleh tajuk tanaman jagung sebesar $1057.6 \mathrm{ft} \mathrm{cd}$. Enam populasi generasi dasar yang digunakan terdiri dari populasi $P_{1}$ sebagai tetua peka (G-203-1), $P_{2}$ sebagai tetua toleran (M7DR 4.8.8), $F_{1}$ $\left(P_{1} \times P_{2}\right), F_{2}\left(F_{1}\right.$ selfing), $B C P_{1}\left(F_{1} \times P_{1}\right)$ dan $\mathrm{BCP}_{2} \quad\left(\mathrm{~F}_{1} \times \mathrm{P}_{2}\right)$. Data parameter hasil pengamatan dianalisis dengan menggunakan uji skala secara individu (scalling test) menurut Hayman (1954) dan Jinks \& Jones, (1958) dan uji skala gabungan (joint scalling test) menurut Bellmann (1973); Singh (1979).

Pada uji skala, pendugaan model genetik dan komponen dari rata-rata generasi dilakukan dengan menggunakan skala individual yaitu: A, B dan C (Bellmann, 1973) dengan menggunakan data dari populasi dasar $P_{1}, P_{2}, F_{1}, F_{2}, B C P_{1}$, dan $B C P_{2}$. Sedangkan pada uji skala gabungan, model diuji dengan uji kebaikan kesesuaian terboboti dan dapat digunakan untuk menduga parameter $\mathrm{m}$, [d], [h] dan interaksi keduanya. Heritabilitas dihitung menggunakan rumus: $h_{b s}^{2}=\sigma^{2} G / \sigma^{2} P$, dimana $h^{2}{ }_{b s}=$ heritabilitas arti luas, $\sigma^{2} G=$ ragam genetik, $\sigma^{2} P=$ ragam fenotipe, heritabilitas arti sempit menggunakan rumus $h_{n s}^{2}=\sigma^{2} A / \sigma^{2} P$, dimana $=\sigma_{A}^{2}$ adalah ragam aditif. Menurut Syukur et al. (2009) kriteria nilai heritabilitas adalah rendah $=$ $\mathrm{h}_{\text {bs }}^{2}<0.2$; sedang $=0.2<\mathrm{h}_{\text {bs }}^{2}<0.5$; dan tinggi $=\mathrm{h}_{\text {bs }}^{2}>0.5$, untuk kriteria antara 
heritabilitas arti sempit dan heritabilitas arti luas adalah sama (Reddy \& Jabeen, 2016).

Pendugaan rasio dominansi dihitung berdasarkan rumus pendugaan potensi rasio (hp) yang disarankan oleh Laurentin \& Karlovsky (2006); Petr \& Frey (1966) yaitu $h p=\left(F_{1}-M P\right) /(H P-M P)$, dimana $F_{1}$ adalah rata-rata $F_{1}, \mathrm{HP}$ adalah rata-rata tetua tahan, dan MP adalah nilai tengah kedua tetua. Berdasarkan nilai potensi rasio, derajat dominansi diklasifikasikan sebagai: $h p=0$ (tidak ada dominansi); $h p=$ 1 atau $h p=-1$ (dominan atau resesif penuh); $0<\mathrm{hp}<1$ (dominan parsial; $-1<$ $\mathrm{hp}<0$ (resesif parsial); dan $\mathrm{hp}>1$ atau $\mathrm{hp}$ $<-1$ (overdominansi). Variabel yang diamati adalah karakter morfologi dan fisiologi yaitu tinggi tanaman, tinggi tongkol, panjang ruas, dan kadar klorofil. Karakter komponen hasil terdiri dari diameter tongkol, jumlah baris per tongkol, bobot tongkol per plot, dan bobot pipil per plot pada populasi generasi dasar.

\section{HASIL DAN PEMBAHASAN}

\section{Uji Skala (Scaling Test)}

Uji skala dilakukan untuk menduga model genetik dan komponen genetik dari rata rata generasi (generation mean) secara individual dengan menggunakan data pengamatan populasi $P_{1}, P_{2}, F_{1}, F_{2}$, $\mathrm{BC}_{\mathrm{P} 1}$, dan $\mathrm{BCP}_{2}$. Hasil uji skala secara individual untuk persilangan antara galur G-2031 x MDR 4.8.8 pada karakter tinggi tanaman, disajikan pada Tabel 1.

Tabel 1. Analisis uji skala persilangan G-2031 x MDR 4.8.8 pada tinggi tanaman

\begin{tabular}{cccccc}
\hline & A & \multicolumn{5}{c}{ B } & C \\
\hline A & $-19,24$ & A & $-10,62$ & A & $-64,06$ \\
$\operatorname{Var}(A)$ & 18,10 & $\operatorname{Var}(B)$ & 16,73 & $\operatorname{Var}(C)$ & 87,30 \\
SE (A) & 4,26 & SE (B) & 4,09 & SE (C) & 9,34 \\
t hit (A) & $-4,52^{*}$ & thit (B) & $-2,60^{*}$ & thit (C) & $-6,87^{*}$ \\
\hline
\end{tabular}

Keterangan: ${ }^{*}=$ berbeda nyata pada $\mathrm{t}(0,05)$; $\mathrm{ns}=$ tidak berbeda nyata; Var= varian; $\mathrm{SE}=$ standar error; $\mathrm{t}$ hit= nilai $\mathrm{t}$ hitung

Pada Tabel 1 memperlihatkan bahwa nilai $t$ hitung untuk skala $A, B$ dan $C$ berbeda nyata (t hit $>1,96$ ). Hal ini mengindikasikan bahwa model aditif- dominan tidak sesuai untuk menduga komponen parameter genetik dan terdapat interaksi non-alelik (terdapat efek epistasis) (Dea et al., 2015).

Tabel 2. Pendugaan Komponen Genetik pada Uji Skala pada Tinggi Tanaman

\begin{tabular}{lcr}
\hline \multicolumn{1}{c}{ Pendugaan Komponen Genetik } & Nilai \\
\hline Pengaruh rata-rata & $\mathrm{m}$ & 165,68 \\
Pengaruh aksi gen aditif & {$[\mathrm{d}]$} & 31,28 \\
Pengaruh aksi gen dominan & {$[\mathrm{h}]$} & 110,48 \\
Pengaruh interaksi aditif $x$ aditif & {$[\mathrm{I}]$} & 34,20 \\
Pengaruh interaksi aditif $x$ dominan & {$[\mathrm{J}]$} & $-4,31$ \\
Pengaruh interaksi dominan $x$ dominan & {$[\mathrm{l}]$} & $-4,35$ \\
\hline
\end{tabular}

Ket: $\mathrm{m}$ : pengaruh rata-rata, [d]: pengaruh aksi gen aditif, [h]: pengaruh aksi gen dominan, [i]: pengaruh interaksi aditif $x$ aditif, [j]: pengaruh interaksi aditif $x$ dominan, [l]: pengaruh interaksi dominan $x$ dominan 
Hasil perhitungan nilai pendugaan komponen genetik adalah pengaruh ratarata $(\mathrm{m})$ sebesar 165,68 , pengaruh aksi gen aditif [d] 31,28 dan pengaruh aksi gen dominan [h] sebesar 110,48 (Tabel 2). Nilai tersebut menunjukkan adanya pengaruh gen dominan yang lebih besar dibandingkan pengaruh aksi gen aditif. Karakter tinggi tanaman sangat dipengaruhi oleh aksi gen dominan dibanding gen aditif, dan arahnya positif.
Besarnya tingkat dominansi dapat dilihat dari derajat dominansi. Hasil perhitungan rasio dominansi persilangan adalah sebesar 2,14 (overdominan) artinya rata-rata tinggi tanaman diatas nilai tengah kedua tetua.

Hal ini juga dapat dilihat pada uji kesesuaian model, terlihat bahwa komponen yang berbeda nyata adalah pengaruh gen aditif [d], pengaruh gen dominan [h], dan pengaruh interaksi aditif $x$ aditif (Tabel 3 ).

Tabel 3. Uji Kesesuaian model aditif-dominan dan interaksi non-alelik

\begin{tabular}{crrcc}
\hline Model & Nilai & Nilai Ragam & Nilai SE & t hit \\
\hline m & 165,68 & 3,54 & 1,88 & $88,11^{*}$ \\
d & 31,28 & 3,15 & 1,77 & $17,61^{*}$ \\
h & 110,48 & 76,87 & 8,77 & $12,60^{*}$ \\
i & 34,20 & 69,19 & 8,32 & $4,11^{*}$ \\
j & $-4,31$ & 6,58 & 2,56 & $-1,68^{\text {ns }}$ \\
I & $-4,35$ & 137,77 & 11,74 & $-0,37^{\text {ns }}$ \\
\hline
\end{tabular}

Keterangan.: S.E. $=$ nilai standar error, ${ }^{*}=$ berbeda nyata pada $t(0,05) ; n s=$ tidak berbeda nyata

Tabel 3 memperlihatkan bahwa pengaruh gen aditif berbeda nyata, pengaruh gen dominan berbeda nyata, dan pengaruh interaksi aditif $\mathrm{x}$ aditif berbeda nyata, hal ini mengindikasikan: (1) aksi gen dominan dan aksi gen aditif keduanya yang berperan pada karakter tinggi tanaman pada jagung, tetapi aksi gen dominan lebih berperan dan terdapat interaksi non-alelik. Efek aditif masing-masing gen akan diteruskan kepada turunannya, sehingga terjadi kemiripan antara tetua dan turunannya (Allard, 1960); (2) Terdapat interaksi non alelik pada populasi jagung yang diuji, yaitu pengaruh interaksi aditif $x$ aditif, mungkin interaksi ini yang menyumbang pengaruh aditif didalam populasi dan nilai aditifnya tidak terlalu tinggi.

\section{Uji Skala Gabungan (Joint Scaling Test)}

Analisis menggunakan uji skala gabungan dengan model genetik aditifdominan $\mathrm{m}$ [d] [h] menunjukkan hal yang sama dengan uji skala, bahwa model aditifdominan tidak sesuai pada karakter tinggi tanaman. Hal ini menunjukkan bahwa pada persilangan tersebut ada interaksi antar alel (Noori et al., 2016; Verma et al., 2018). Pada analisis ini terdapat delapan model genetik yang diuji menggunakan uji $\chi^{2}$ (Tabel 4), sedangkan model enam parameter $\mathrm{m} \mathrm{[d]} \mathrm{[h]} \mathrm{[i]} \mathrm{[j]} \mathrm{[l]} \mathrm{tidak} \mathrm{dapat}$ diuji karena kekurangan derajat bebas.

Model genetik dengan nilai $\chi^{2}$ hitung yang tidak berbeda nyata (ns) terhadap $\chi^{2}$ tabel dinyatakan sebagai model genetik yang sesuai untuk karakter tinggi tanaman pada jagung. Berdasarkan uji $\chi^{2}$, terdapat tiga model genetik yang sesuai, yaitu $\mathrm{m}$ [d] 
[h] [i], model m [d] [h] [i] [j], dan model m [d] [h] [i] [l].

Tabel 4. Pendugaan model genetik pada uji skala gabungan

\begin{tabular}{|c|c|c|}
\hline Model Genetik & $\chi^{2}$ hitung & $\chi^{2}$ tabe \\
\hline $\mathrm{m}$ [d] & $844,49 *$ & 9,49 \\
\hline $\mathrm{m}[\mathrm{d}][\mathrm{h}]$ & $49,22 *$ & 7,81 \\
\hline$m[d][h][i]$ & $2,89^{\mathrm{ns}}$ & 5,99 \\
\hline$m[d][h][j]$ & $48,65^{*}$ & 5,99 \\
\hline$m[d][h][l]$ & $18,27^{*}$ & 5,99 \\
\hline$m[d][h][i][j]$ & $0,14^{\mathrm{ns}}$ & 3,84 \\
\hline $\mathrm{m}[\mathrm{d}][\mathrm{h}][\mathrm{i}][\mathrm{l}]$ & $2,82^{\mathrm{ns}}$ & 3,84 \\
\hline $\mathrm{m}[\mathrm{d}][\mathrm{h}][\mathrm{j}][\mathrm{l}]$ & $16,91^{*}$ & 3,84 \\
\hline
\end{tabular}

Selanjutnya, komponen genetik individual dari model yang sesuai diuji menggunakan uji t-student (Tabel 5). Komponen genetik yang berbeda nyata dianggap memberikan sumbangan terhadap model (Li et al., 2008; Ljubičić et al., 2016). Hasil uji t-student pada masingmasing komponen genetik individual menunjukkan bahwa model $\mathrm{m}$ [d] [h] [i] mempunyai semua nilai komponen genetik yang berbeda nyata baik pengaruh gen aditif, dominan, dan interaksi aditif $x$ aditif. Pada model $m$ [d] [h] [i] [j], semua komponen berbeda nyata tetapi interaksi aditif $\mathrm{x}$ dominan tidak nyata, dan pada model $m$ [d] [h] [i] [l], semua komponen juga berbeda nyata kecuali interaksi dominan $\mathrm{x}$ dominan. Hasil tersebut menunjukkan bahwa model yang paling sesuai untuk karakter tinggi tanaman adalah model $\mathrm{m}$ [d] [h] [i] karena semua komponen genetiknya memberikan sumbangan yang nyata terhadap model genetik ini.

Adanya pengaruh aditif [d], dominan [h] dan [i] (interaksi aditif $x$ aditif) serta pengaruh dominan lebih besar dari aditif secara teoritis dapat diasumsikan bahwa populasi ini dapat dimanfaatkan untuk membuat jagung hibrida. Nilai dominan [h] mempunyai nilai positif dan interaksi aditif $x$ aditif [i] positif tetapi nilainya kecil, dan jika kita buat nilai rata-rata populasi $F_{1}$ $(219,84)$ lebih besar dibandingkan rata-rata kedua tetuanya $((179,16+107,97) / 2=$ $143,56)$ sangat signifikan penambahannya, sehingga populasi persilangan ini sangat cocok untuk dimanfaatkan dalam pembuatan jagung hibrida.

Tabel 5. Pendugaan komponen genetik individual pada karakter tinggi tanaman pada jagung persilangan galur G-2031 x MDR 4.8.8

\begin{tabular}{lcc}
\hline Model & $\begin{array}{c}\text { Komponen } \\
\text { genetik }\end{array}$ & $\begin{array}{c}\text { Nilai Komponen } \\
\text { genetik }\end{array}$ \\
\hline $\mathrm{m}[\mathrm{d}]$ & $\mathrm{m}$ & $111,97 \pm 28,40^{*}$ \\
{$[\mathrm{~h}][\mathrm{i}]$} & {$[\mathrm{d}]$} & $33,44 \pm 1,22^{*}$ \\
& {$[\mathrm{~h}]$} & $108,05 \pm 5,50^{*}$ \\
& {$[\mathrm{i}]$} & $30,64 \pm 4,50^{*}$ \\
$\mathrm{~m}[\mathrm{~d}]$ & $\mathrm{m}$ & $112,16 \pm 3,94^{*}$ \\
{$[\mathrm{~h}][\mathrm{i}]$} & {$[\mathrm{d}]$} & $35,70 \pm 1,82^{*}$ \\
{$[\mathrm{j}]$} & {$[\mathrm{h}]$} & $107,94 \pm 5,50^{*}$ \\
& {$[\mathrm{i}]$} & $31,62 \pm 4,50^{*}$ \\
& {$[\mathrm{j}]$} & $-8,50 \pm 5,12 \mathrm{~ns}$ \\
$\mathrm{~m}[\mathrm{~d}]$ & $\mathrm{m}$ & $110,03 \pm 8,51^{*}$ \\
{$[\mathrm{~h}][\mathrm{i}]$} & {$[\mathrm{d}]$} & $33,34 \pm 1,28^{*}$ \\
{$[\mathrm{l}]$} & {$[\mathrm{h}]$} & $112,82 \pm 19,37^{*}$ \\
& {$[\mathrm{i}]$} & $32,41 \pm 8,25^{*}$ \\
& {$[\mathrm{l}]$} & $-3,01 \pm 11,71^{\text {ns }}$ \\
\hline
\end{tabular}

Ket: $\mathrm{m}$ : pengaruh rata-rata; [d]: pengaruh aksi gen aditif; [h]: pengaruh aksi gen dominan; [i]: pengaruh interaksi aditif $\mathrm{x}$ aditif; [j]: pengaruh interaksi aditif $\mathrm{x}$ dominan; [l]: pengaruh interaksi dominan $\mathrm{x}$ dominan

Rekomendasi perakitan hibrida biasanya diberikan bila terdapat efek overdominan yang menyebabkan terjadinya efek heterosis. Heritabilitas arti luas $\left(h^{2}{ }_{b s}\right)$ untuk karakter tinggi tanaman pada jagung persilangan galur G-2031 x MDR 4.8.8 mempunyai nilai 1,23 , termasuk katagori tinggi (Barmawi et al., 2013; Syafruddin et 
al., 2012; Trikoesoemaningtyas et al., 2017). Heritabilitas arti luas yang tinggi menunjukkan bahwa seleksi yang dilakukan pada karakter ini akan memberikan peluang mendapatkan kemajuan seleksi yang tinggi (kemajuan genetik " $\Delta G$ ") (Shereen \& El-Nahrawy, 2018).

Heritabilitas arti sempit $\left(\mathrm{h}_{\mathrm{ns}}^{2}\right)$ merupakan gambaran dari genetik aditif yang diwariskan kepada keturunannya. Nilai heritabilitas arti sempit mempunyai nilai 0.75 , termasuk katageri tinggi (Tabel 6), menunjukkan bahwa seleksi pada karakter tersebut memberikan peluang besar untuk mendapatkan kemajuan seleksi yang lebih besar, sehingga karakter tinggi tanaman dapat digunakan dalam kriteria seleksi untuk pembentukan jagung hibrida.

Tabel 6. Nilai heritabilitas pada karakter tinggi tanaman

\begin{tabular}{ccc}
\hline Heritabilitas & Nilai & Kategori \\
\hline $\mathrm{h}^{2}{ }_{\text {bs }}$ & 1,23 & tinggi \\
$\mathrm{h}^{2}{ }_{\text {ns }}$ & 0,75 & tinggi
\end{tabular}

Ket. : $\quad$ bs= broad sense heritability (heritabilitas arti luas); ns= narrow sense heritability (heritabilitas arti sempit; kriteria nilai heritabilitas rendah $=h^{2}$ bs $<0,2$, sedang $=0,2$ $<\mathrm{h}_{\text {bs }}^{2}<0,5$ dan tinggi $=\mathrm{h}^{2}$ bs $>0,5$

Rekapitulasi hasil analisis menggunakan uji skala individual dan uji skala gabungan terhadap karakter tinggi tanaman, tinggi tongkol, panjang ruas, kadar klorofil, diameter tongkol, jumlah baris per tongkol, bobot tongkol per plot dan bobot pipil per plot, disajikan pada Tabel 7.

Sesuai dengan Tabel 7, rekapitulasi dari hasil uji skala dan uji skala gabungan pada semua karakter yang diamati dari hasil persilangan antara G-2031 x M7DR-4.8.8 menunjukkan bahwa tidak terdapat kesesuaian dengan model genetik aditifdominan dan terdapat interaksi nonalelik, kecuali karakter jumlah baris per tongkol terdapat kesesuaian model dengan aditif-dominan dan tidak terdapat efek epistasis. Untuk semua karakter mempunyai tingkat dominansi dengan kategori overdominan, kecuali karakter panjang ruas dan diameter batang mempunyai tingkat dominansi dengan kategori resesif-parsial, hal ini sesuai penelitian (Yuan et al., 2012). Berdasarkan hasil uji kesesuaian model dan pendugaan model genetik dapat diketahui bahwa model genetik yang sesuai dengan karakter tinggi tanaman adalah $\mathrm{m}$ [d] [h] [i]; karakter tinggi tongkol adalah $\mathrm{m} \mathrm{[d]} \mathrm{[h]} \mathrm{[j]}$ [l]; karakter panjang ruas adalah $\mathrm{m}$ [d] [h] [i] [l]; karakter diameter tongkol adalah $\mathrm{m}$ [d] [h] [i] [l]; karakter bobot tongkol per tongkol adalah $\mathrm{m} \mathrm{[d]} \mathrm{[h]} \mathrm{[i]} \mathrm{[l];} \mathrm{dan} \mathrm{karakter}$ bobot pipil per tongkol adalah $\mathrm{m}$ [d] [h] [i]. Pada karakter kadar klorofil dan jumlah baris per tongkol tidak ada yang sesuai dengan model genetik yang diduga.

Nilai heritabilitas arti luas semua karakter yang diamati antara 0,55-11,23 dengan kategori rendah sampai tinggi. Nilai heritabilitas arti sempit antara 0,10-9,8 dengan kategori rendah sampai tinggi. Karakter-karakter yang memiliki nilai heritabilitas tinggi adalah karakter tinggi tanaman, tinggi tongkol, kadar klorofil, dan bobot tongkol per plot sehingga karakter tersebut dapat dijadikan tolak ukur dalam seleksi untuk pembentukan varietas hibrida pada jagung toleran naungan. 
Tabel 7. Rekapitulasi hasil uji skala individu dan uji skala gabungan pada persilangan antara G2031 x MDR 4.8.8

\begin{tabular}{|c|c|c|c|c|c|c|c|c|}
\hline Model & Ttan & Ttong & P Ruas & KLO & DT & JBT & BTT & BPT \\
\hline \multicolumn{9}{|l|}{ Uji Skala : } \\
\hline$A$ & $*$ & $*$ & $*$ & ns & $*$ & ns & ns & ns \\
\hline B & $*$ & $*$ & $*$ & $*$ & ns & ns & $*$ & $*$ \\
\hline $\mathrm{C}$ & $*$ & $*$ & ns & $*$ & $*$ & ns & $*$ & $*$ \\
\hline $\begin{array}{l}\text { Kesesuain model } \\
\text { (aditif-dominan): }\end{array}$ & $\begin{array}{l}\text { tidak } \\
\text { sesuai }\end{array}$ & $\begin{array}{c}\text { tidak } \\
\text { sesuai }\end{array}$ & $\begin{array}{c}\text { tidak } \\
\text { sesuai }\end{array}$ & $\begin{array}{c}\text { tidak } \\
\text { sesua } \\
\text { i }\end{array}$ & $\begin{array}{l}\text { tidak } \\
\text { sesuai }\end{array}$ & sesuai & $\begin{array}{l}\text { tidak } \\
\text { sesuai }\end{array}$ & $\begin{array}{l}\text { tidak } \\
\text { sesuai }\end{array}$ \\
\hline $\begin{array}{l}\text { Derajat dominansi: } \\
\text { Kesesuaian model: } \\
\text { (aditif-dominan- } \\
\text { epistasis) }\end{array}$ & OD & OD & $\mathrm{RP}$ & OD & OD & OD & OD & OD \\
\hline$M$ & $*$ & $*$ & $*$ & $*$ & $*$ & $*$ & $*$ & $*$ \\
\hline [d] & $*$ & $*$ & $*$ & $*$ & $*$ & ns & $*$ & $*$ \\
\hline$[\mathrm{h}]$ & $*$ & $*$ & $*$ & $*$ & $*$ & $*$ & $*$ & $*$ \\
\hline [i] & $*$ & ns & $*$ & $*$ & $*$ & ns & $*$ & $*$ \\
\hline [j] & ns & $*$ & ns & ns & ns & ns & ns & $*$ \\
\hline$[\mathrm{l}]$ & ns & $*$ & $*$ & ns & $*$ & ns & $*$ & ns \\
\hline \multicolumn{9}{|l|}{$\begin{array}{l}\text { Pendugaan model } \\
\text { genetik: }\end{array}$} \\
\hline $\mathrm{m}[\mathrm{d}]$ & $*$ & $*$ & $*$ & $*$ & $*$ & $*$ & $*$ & $*$ \\
\hline$m[d][h]$ & $*$ & $*$ & $*$ & $*$ & $*$ & ns & $*$ & $*$ \\
\hline$m[d][h][i]$ & ns & $*$ & $*$ & ns & $*$ & ns & $*$ & ns \\
\hline$m[d][h][j]$ & $*$ & $*$ & $*$ & $*$ & $*$ & ns & $*$ & $*$ \\
\hline $\mathrm{m}[\mathrm{d}][\mathrm{h}][\mathrm{I}]$ & $*$ & $*$ & $*$ & $*$ & $*$ & ns & $*$ & $*$ \\
\hline$m[d][h][i][j]$ & ns & $*$ & $*$ & ns & $*$ & ns & $*$ & ns \\
\hline$m$ [d] [h] [i] [l] & ns & $*$ & ns & ns & ns & ns & ns & $*$ \\
\hline$m[d][h][j][l]$ & $*$ & ns & $*$ & $*$ & $*$ & ns & $*$ & $*$ \\
\hline Model yang sesuai: & $\begin{array}{c}\mathrm{m}[\mathrm{d}][\mathrm{h}] \\
{[\mathrm{i}]}\end{array}$ & $\begin{array}{c}\mathrm{m}[\mathrm{d}][\mathrm{h}] \\
{[\mathrm{j}][\mathrm{l}]}\end{array}$ & $\begin{array}{c}\mathrm{m}[\mathrm{d}][\mathrm{h}] \\
{[\mathrm{i}][\mathrm{l}]}\end{array}$ & $\begin{array}{l}\text { tidak } \\
\text { ada }\end{array}$ & $\begin{array}{c}\mathrm{m}[\mathrm{d}][\mathrm{h}][\mathrm{i} \\
][\mathrm{l}]\end{array}$ & $\begin{array}{l}\text { tidak } \\
\text { ada }\end{array}$ & $\begin{array}{c}\mathrm{m}[\mathrm{d}][\mathrm{h}] \\
{[\mathrm{i}][\mathrm{l}]}\end{array}$ & $\begin{array}{c}\mathrm{m}[\mathrm{d}][\mathrm{h} \\
][\mathrm{i}]\end{array}$ \\
\hline \multicolumn{9}{|l|}{ Heritabilitas: } \\
\hline $\mathrm{h}_{\text {bs }}^{2}$ (arti luas) & 1.23 & 1.78 & 1.19 & 1.0 & 0,67 & 0.91 & 11,23 & 0.55 \\
\hline $\mathrm{h}_{\mathrm{ns}}^{2}$ (arti sempit) & 0.75 & 0.55 & 0.34 & 0.65 & 0,18 & 0.16 & 9,88 & 0,10 \\
\hline
\end{tabular}

\section{SIMPULAN}

Dari hasil penelitian dapat disimpulkan bahwa model genetik yang sesuai adalah karakter tinggi tanaman: $\mathrm{m}[\mathrm{d}][\mathrm{h}][\mathrm{i}]$; karakter tinggi tongkol: $\mathrm{m}[\mathrm{d}][\mathrm{h}][\mathrm{j}][\mathrm{l}]$; karakter panjang ruas: $\mathrm{m}[\mathrm{d}][\mathrm{h}][\mathrm{i}][\mathrm{l}]$; karakter diameter tongkol: $\mathrm{m}[\mathrm{d}][\mathrm{h}][\mathrm{i}][\mathrm{l}]$; karakter bobot tongkol: $m[d][h][i][l] ;$ dan karakter bobot pipil per tongkol yaitu: $\mathrm{m}[\mathrm{d}][\mathrm{h}][\mathrm{i}]$. Terdapat kesesuaian model aditif-dominan dengan dominansi tinggi 
tanpa efek epistasis pada karakter jumlah baris per tongkol, namun tidak ada kesesuaian model genetik yang diduga. Sedangkan, karakter kadar klorofil tidak terdapat model yang sesuai dengan model aditif-dominan.

\section{UCAPAN TERIMA KASIH}

Terima kasih kami ucapkan sebesarbesarnya kepada Direktorat Jenderal Pendidikan Tinggi Ristekdikti atas Beasiswa BPP-DN Tahun 2013 kepada penulis dan Puslitbangtan Kementerian Pertanian atas dukungan dana hibah penelitian melalui skema KKP3N Tahun 2014 \& 2015.

\section{DAFTAR PUSTAKA}

Barmawi, M., Sa'diyah, N., \& Yantama, E. (2013). Kemajuan genetik dan heritabilitas karakter agronomi kedelai (Glycine max [L.] Merrill) generasi F2 persilangan Wilis Dan Mlg2521. In Prosiding SEMIRATA 2013 (Vol. 1, pp. 77-82). Retrieved from http://jurnal.fmipa.unila.ac.id /index.php/semirata/article/view/590

Bellmann, K. (1973). MATHER, K., and J. L. JINKS: Biometrical Genetics. The study of continuous Variation. Chapman and Hall, London 1971. XII, 382 S., $f$ 8.00. Biometrische Zeitschrift, 15(5), 364-365. https://doi.org/10.1002/bimj.197301 50511

Dea, M. Y., Moussa, S., Ibnou, D., Nasser, Y. K., \& Adam, A. (2015). Generation mean analysis to estimate genetic parameters of some traits for rice weed competitiveness. Jounal of Plant Breeding and Crop Science, 7(6), 163-169. https://doi.org/10.5897 /JPBCS2014.0450

Deshmukh, R. A., \& Gawande, V. I. (2016).
Generation mean analysis for seed yield and its contributing traits in chickpea ( Cicer arietinum L .). Electronic Journal of Plant Breeding, 7(1), 86-93. https://doi.org/10.5958 /0975-928X.2016.00012.0

Farshadfar, E., Zali, H., \& Mohammadi, R. (2011). Evaluation of phenotypic stability in chickpea genotypes using GGE-Biplot. Annals of Biological Research, 2(6), 282-292.

Gao, L., Xu, H., Bi, H., Xi, W., Bao, B., Wang, X., Chang, Y. (2013). Intercropping competition between apple trees and crops in agroforestry systems on the Loess Plateau of China. PLOS ONE, 8(7), e70739. https://doi.org/ 10.1371/journal.pone.0070739

Hairiah, K., Noordwijk, V., Meine, \& Suprayogo, D. (2002). Interaksi antara Pohon-Tanah-Tanaman Semusim: Kunci Keberhasilan atau Kegagalan dalam Sistem Agroforestri. In Bahan ajar 2. Retrieved from http://www.worldagroforestry.org/se a/Publications/files/lecturenote/LNOO 35-06.pdf

Hayman, B. (1954). The theory and analysis of diallel crosses. Genetics, 39(1), 789-809.

Jinks, J. \& Jones, R. M. (1958). Estimation of the components of heterosis. Genetics, 43(2), 223-234. Retrieved from https://www.ncbi.nlm.nih.gov /pmc/articles/PMC1209876/

Krisnawati, H., Varis, E., Kallio, M. \& Kanninen, M. (2011). Paraserienthes falcataria (L.) Nielsen: ekologi, silvikultur dan produktivitas. Bogor: CIFOR. Retrieved from http://www.cifor.org/publications/pd f_files/Books/BKrisnawati1109.pdf

Kumar, A., Kumar, J., Singh, R., Garg, T., 
Chhuneja, P., Balyan, H. S., \& Gupta, P. K. (2009). QTL analysis for grain colour and pre-harvest sprouting in bread wheat. Plant Science, 177(2), 114-122. https://doi.org/10.1016 /j.plantsci.2009.04.004

Laurentin, H. E., \& Karlovsky, P. (2006). Genetic relationship and diversity in a sesame (Sesamum indicum L.) germplasm collection using amplified fragment length polymorphism (AFLP). BMC Genetics, 7(July), 431436. https://doi.org/10.1186/14712156-7-10

Li, H., Ribaut, J. M., Li, Z., \& Wang, J. (2008). Inclusive composite interval mapping (ICIM) for digenic epistasis of quantitative traits in biparental populations. Theoretical and Applied Genetics, 116(2), 243-260. https://doi.org/10.1007/s00122-0070663-5

Liu, W., \& Tollenaar, M. (2009). Physiological Mechanisms Underlying Heterosis for Shade Tolerance in Maize. Crop Science, 49(5), 18171826. https://doi.org/10.2135 /cropsci2008.07.0423

Ljubičić, N., Petrović, S., Dimitrijević, M., \& Hristov, N. (2016). Genetic Analysis of some Important Quantitative Traits in Bread Wheat. Journal of Crop Breeding and Genetics, 2(2), 47-53. Retrieved from https://dergipark.org. tr/download/article-file/333355

Noori, Z., Saleh, G., Foroughi, M., Behmaram, R., \& Kashiani, P. (2016). Generation mean analysis for forage yield and quality in Kenaf. Iranian Journal of Genetics and Plant Breeding, 5(2), 23-31.

Petr, F. C., \& Frey, K. J. (1966). Genotypic correlations, dominance, and heritability of quantitative characters in oats. Crop Science, 6(3), 259-262. https://doi.org/doi:10.2135/cropsci1 966.0011183X000600030013x

Rao, M., Grithlahre, S., Bisen, P., Loitongbam, B., Dar, M. H., Zaidi, N. W., ... Singh, P. K. (2017). Generation mean analysis for grain yield and its component traits in submergence rice. SABRAO Journal of Breeding and Genetics, 49(4), 327-335. Retrieved from https://www.researchgate.net /publication/321386177_Generation mean_analysis_for_grain_yield_and_i ts_component_traits_in_submergenc e_rice

Reddy, V. R. A. M., \& Jabeen, F. (2016). Narrow sense heritability, corelation and path analysis in maize ( Zea mays L .). Sabrao Journal of Breeding and Genetics, 48(2), 120-126. Retrieved from http://sabraojournal.org/wpcontent/uploads/2018/01/SABRAO-JBreed-Genet-48-2-120-126-Reddy1.pdf

Robert W. Allard. (1960). Principles of Plant Breeding. New York/Chichester /London/Singapore/Sidney/Toronto: John Wileys \& Sons.

Ruswandi, D., Waluyo, B., Takdir Mak, A., Azizah, E., Yuwariah, Y., \& Rostini, N. (2017). Simple sequence repeats analysis of new Indonesian maize inbred. Asian Journal of Crop Science, 9(4),141-148. https://doi.org/10. 3923/ajcs.2017.141.148

Said, A. A. (2014). Generation mean analysis in wheat ( Triticum aestivum L .) under drought stress conditions. Annals of Agricultural Sciences, 59(2), 177-184. https://doi.org/10.1016 /j.aoas.2014.11.003

Senoaji, G. (2012). Pengelolaan lahan dengan sistem agroforestry oleh masyarakat baduy di banten selatan. 
Jurnal Bumi Lestari, 12(2), 283-293. Retrieved from http://docplayer.info /44164653-Pengelolaan-lahandengan-sistem-agroforestry-olehmasyarakat-baduy-di-bantenselatan.html

Shereen, M., \& El-Nahrawy. (2018). AgroMorphological and Genetic Parameters of some Cowpea Genotypes. Alexandria Science Exchange Journal, 39(1), 56-64. Retrieved from https://pdfs. semanticscholar.org/ed09/07e65dc10 2f083a268848cb556e3ede50ae8.pdf

Singh, H. K. and B. D. C. (1979). Biometrical Methods in Quantitative Genetic Analysis. Ludhiana. New Delhi: Kalyani Publisher.

Syafii, M., Cartika, I., \& Ruswandi, D. (2015). Multivariate analysis of genetic diversity among some maize genotypes under maize- albizia cropping system in Indonesia. Asian Journal of Crop Science, 7(4), 244255. https://doi.org/10.3923/ajcs.

2015.244.255

Syafii, M., Cartika, I., \& Ruswandi, D. (2016). Penilaian tingkat respon galur jagung Unpad toleran naungan pada sistem Agroforestri dengan Albizia (Albizia falcataria L.) berdasarkan komponen indeks toleran. Agrotek Indonesia, 1(2), 73-80. https://doi.org/http://dx.doi.org/10.3 3661/jai.v1i2.316.g312

Syafruddin, Azrai, M., \& Suwarti. (2012). Genotipe jagung hibrida toleran N rendah. In Prosiding Insinas 2012 (pp. 287-292). Retrieved from http://biofarmaka.ipb.ac.id/biofarma ka/2013/PIRS 2012 - file-PGTeX_48.pdf

Syukur, M., Sujiprihati, S., \& Koswara, J. (2009). Ketahanan terhadap
Antraknosa yang Disebabkan oleh Colletotrichum acutatum pada Beberapa Genotipe Cabai ( Capsicum annuum L .) dan Korelasinya dengan Kandungan Kapsaicin dan Peroksidase Resistance of Several Capsicum annuum L . Genotypes to Anthracnose ca. J. Agron. Indonesia, 37(3), 233-239. Retrieved from http://pkht.ipb.ac.id/wpcontent/uploads/2015/11/2009.pdf

Trikoesoemaningtyas, Wirnas, D., Leonardo Saragih, E., Puspita Rini, E., Sari, M., Marwiyah, S., \& Didy Sopandie, D. (2017). Kendali genetik karakter morfologi dan agronomi pada tiga populasi sorgum (Sorghum bicolor (L.) Moench). Jurnal Agronomi Indonesia (Indonesian Journal of Agronomy), 45(3), 285-291. https://doi.org /10.24831/jai.v45i3.18387

Verma, S., Malik, M., Kumar, P., Choudhary, D., Jaiwal, P., \& Jaiwal, R. (2018). Susceptibility of four Indian grain legumes to three species of stored pest, bruchid (Callosobruchus) and effect of temperature on bruchids. International Journal of Entomology Research, 3(2), 5-10. Retrieved from http://www.entomol ogyjournals.com/archives/2018/vol3/ issue2/3-1-33

Wang, L., Deng, F., Ren, W., \& Yang, W. (2013). Effects of shading on starch pasting characteristics of indica hybrid rice (Oryza sativa L.). PLoS ONE, 8(7), e68220. https://doi.org/https://doi.org/10.13 71/journal.pone. 0068220

Yuan, L., Tang, J., Wang, X., \& Li, C. (2012). QTL Analysis of Shading Sensitive Related Traits in Maize under Two Shading Treatments. PLOS ONE, 7(6), e38696. https://doi.org/10.1371/jou rnal.pone.0038696 